\title{
Quality profile of catfoods
}

\author{
Perfill de qualidade dos catfoods \\ Perfil de calidad de los catfoods
}

Received: 01/21/2021 | Reviewed: 01/23/2021 | Accept: 01/24/2021 | Published: 01/31/2021

\author{
André Gomes Faria \\ ORCID: https://orcid.org/0000-0003-3364-1288 \\ Universidade José do Rosário Vellano, Brazil \\ E-mail: andrefaria15.232@gmail.com \\ Alexandre José de Oliveira \\ ORCID: https://orcid.org/0000-0002-1918-0422 \\ Universidade José do Rosário Vellano, Brazil \\ E-mail: alexandreburns@gmail.com \\ Gessica Corrêa \\ ORCID: https://orcid.org/0000-0002-0886-9347 \\ Universidade José do Rosário Vellano, Brazil \\ E-mail: gessica.cgoncalves@gmail.com \\ Édina de Fátima Aguiar \\ ORCID: https://orcid.org/0000-0002-7883-5628 \\ Universidade José do Rosário Vellano, Brazil \\ E-mail: edina.aguiar@unifenas.br \\ Luciana Rosa Alves Rufino \\ ORCID: https://orcid.org/0000-0002-8364-9379 \\ Universidade José do Rosário Vellano, Brazil \\ E-mail: lufeliciano1@hotmail.com \\ Nhayandra Christina Dias e Silva \\ ORCID: https://orcid.org/0000-0003-1804-8312 \\ Universidade José do Rosário Vellano, Brazil \\ E-mail: nhayandra_dias@yahoo.com.br \\ Nelma de Mello Silva Oliveira \\ ORCID: https://orcid.org/0000-0002-1918-0422 \\ Universidade José do Rosário Vellano, Brazil \\ E-mail: nelma.oliveira@unifenas.br
}

\begin{abstract}
There is a series of feeds aimed at cats in the pet market, amongst which extruded feeds stand out, because their manufacturing process goes through thermal treatment. Such process is the main factor for the reduction of microbial contamination, as well as the action of the water in the feed. This is responsible for controlling degradation by bacteria and fungi after the manufacturing process. After opening the packages, there are several ways and factors that lead to contamination in feed. This study aimed at assessing cat feeds for their microbioligical and brotmathological content. For this, we analyzed different kinds of cat feed in the original package and traded in bulk, with different types of classification as to their quality. The assessments consisted in finding if the nutrients of the feeds were within the minimum levels required by the Manual Pet Food Brazil (2014). Analyses were performed to determine the presence of Salmonellae spp., Eschirichia coli, coliforms at $35^{\circ} \mathrm{C}$ e $45^{\circ} \mathrm{C}$, Aspergillus spp e Penicillium spp; and also, for the existence of aflatoxin in the feeds. The microbiological results showed that the feeds traded unpackaged in the city of Alfenas Minas Gerais obtained results with higher levels of contamination in relation to those traded in their original packaging. This showed that the feeds exposed to the environment may compromise their microbiological quality and endanger the pets' health. These results prove the need of greater restrictions to the trading of feeds in bulk, so that the degradation of the product is reduced, thus preserving the quality of the feed and the safety of the cats.
\end{abstract}

Keywords: Aflatoxin; Bromatological; Microbiological.

\section{Resumo}

No mercado pet existe uma série de alimentos destinados a gatos, dentre eles destacam-se as rações extrusadas, cujo processo de fabricação passa por um tratamento térmico. Esse processo é o principal fator para redução da contaminação microbiana e da atividade de água na ração e, isso, é o que faz com que a degradação por bactérias e fungos fique controlada após a fabricação. Após aberto as embalagens existem diversas formas e vetores que levam à contaminação para as rações. Objetivou-se com este estudo avaliar a microbiologicamente e bromatologicamente as rações para gatos armazenadas em embalagem original de fábrica e comercializadas abertas (a granel) de diferentes tipos de classificação quanto a qualidade. As avaliações consistiram em determinar se os nutrientes das rações estão 
dentro dos niveis minimos de garatia exigidos pelo Manual Pet Food Brasil (2014); determinar a presença de Salmonellas spp. , Eschirichia coli, coliformes a $35^{\circ} \mathrm{C}$ e $45^{\circ} \mathrm{C}$, Aspergillus spp e Penicillium spp; e determinar a presença de aflatoxina nas rações. Os resultados microbiológicos mostram que as rações comercializadas a granel na cidade de Alfenas MG, obtiveram resultados com incidência de contaminações superiores às comercializadas em suas embalagens originais, evidenciando que quando as mesmas são expostas ao ambiente, podem comprometer a qualidade microbiológica, o que pode trazer risco à saúde animal. Os resultados obtidos comprovam a necessidade de maiores restrições à venda das rações comercializada a granel a fim de minimizar a depreciação do produto, preservando, assim, a qualidade da ração e garantindo segurança alimentar dos gatos.

Palavras-chave: Aflatoxina; Bromatológia; Microbiológicos.

\section{Resumen}

Existe una serie de piensos destinados a gatos en el mercado de mascotas, entre los que destacan los piensos extruidos, porque su proceso de fabricación pasa por un tratamiento térmico. Dicho proceso es el factor principal para la reducción de la contaminación microbiana, así como la acción del agua en el alimento. Este es el responsable de controlar la degradación por bacterias y hongos después del proceso de fabricación. Después de abrir los paquetes, hay varias formas y factores que conducen a la contaminación del alimento. Este estudio tuvo como objetivo evaluar los alimentos para gatos por su contenido microbiológico y brotmatológico. Para ello, analizamos diferentes tipos de pienso para gatos en el envase original y comercializados a granel, con diferentes tipos de clasificación en cuanto a su calidad. Las evaluaciones consistieron en encontrar si los nutrientes de los alimentos se encontraban dentro de los niveles mínimos requeridos por el Manual Pet Food Brasil (2014). Se realizaron análisis para determinar la presencia de Salmonellae spp., Eschirichia coli, coliformes a $35^{\circ} \mathrm{C}$ e $45^{\circ} \mathrm{C}$, Aspergillus spp e Penicillium spp; y también por la existencia de aflatoxinas en los piensos. Los resultados microbiológicos mostraron que los alimentos comercializados sin empaquetar en la ciudad de Alfenas Minas Gerais obtuvieron resultados con mayores niveles de contaminación en relación a los comercializados en su empaque original. Esto mostró que los alimentos expuestos al medio ambiente pueden comprometer su calidad microbiológica y poner en peligro la salud de las mascotas. Estos resultados evidencian la necesidad de mayores restricciones a la comercialización de piensos a granel, de forma que se reduzca la degradación del producto, preservando así la calidad del pienso y la seguridad de los gatos.

Palabras clave: Aflatoxina; Bromatológica; Microbiológica.

\section{Introduction}

Brazil is the second greatest cat breeder in the world, with approximately 23.9 million cats, making them important pets in the market. The Associação Brasileira da Indústria de Produtos para Animais de Estimação (Abinpet) reports revenues of 20.3 billions reais, being $73.9 \%$ from feeds, according to data collected in 2018.

In the pet Market there is a variety of cat feeds, which may be pelleted, extruded, mix of grains or supplements. Amongst the commercialized pet feeds, the extruded feeds stand out. The manufacturing process of these feeds goes through thermic treatment, which is the main factor for the reduction of microbial contamination and the action of water in the feed. This makes the degradation caused by bacteria and fungi to be controlled.

The quality of the raw materials used in pet feeds is important for the efficiency of the ingredients/ nutrients in animal health (França, et al., 2011). Butolo (2002) states that the raw materials may have increased moist if they are stored incorrectly, favoring their contamination.

Therefore, the quality of grains and their storage is important because the poisoning microbiota may be eliminated by the high temperatures in the extruding process, while the fungal metabolites and the bacterial toxins may remain after the processing.

There are several ways and vectors that lead to feed contamination such as: cockroaches (Klowden \& Greenberg 1976; Kopanic et al. 1994), rats, mice and ants (Singhi et al. 1980). Barbosa et al (2014) report that the main form of contamination in commercialized feeds in bulk is through handling and contact with the air. The fungal contamination and their metabolites may cause economic losses associated to the reduction of nutrients, decrease of palatability, and the presence of microtoxins may affect the health of the animal. 
Klowden and Greenberg (1976) states that the quality of the feed is an important factor and that the exposure to the environment may compromise its properties the main factor for the decrease in quality is the contamination by microorganisms and this may be linked to the storage conditions (Berchieri Júnior et al. 1983; Berchieri Júnior et al. 1989).

The feeds for cats have to be within the bromatologic and microbiologic values established by ABINPET in order to ensure the safety of the feed and the animals' health. The rules for the production of feeds set by ABINPET, described in the Manual Pet Food Brazil (2014), determine the absence of Salmonellas spp., Eschirichia coli, coliforms at $35^{\circ} \mathrm{C}$, coliforms at $45^{\circ} \mathrm{C}$, molds and yeasts. These rules define the limits of contamination by metabolites produced by fungi, such as aflatoxins, at an acceptable level up to $200 \mathrm{ppb}$.

The assessment of fungal metabolites after the extruding process in packaged feeds at in those sold in bulk will serve as quality parameters.

The aim of the study was to evaluate microbiological and bromatological content of different qualities of cat feeds traded in bulk, as well as enclosed in the original package.

\section{Materials and Methods}

The present study was developed at the Microbiology Laboratory of the Universidade José do Rosário Vellano (UNIFENAS), campus of Alfenas MG and at Laboratory of Clinical Analyses Unit Valinhos SP (CBO).

The samples of the feeds were collected at the stores of Alfenas, State of Minas Gerais, in a total of 30 samples of cat extruded feed. Among these 5 were classified as economic feed; 5 were premium feed and 5 super premiums (according to the manufacturers' specifications). $1 \mathrm{~kg}$ of each of the feeds was collected from enclosed packages as well as from unpackaged ones. For the analyses the descriptive statistic design was used.

From 5 different feed labels, 100g were taken from each one to perform the bromatological assessment. These samples were homogenized in three pools according to the quality classification (super premium, premium and economic), and also according to the way they were sold (closed packages and in bulk), totalizing 6 samples.

After composing the feed pools, these were evaluated according to grey tests (Association of Official Analytical Chemistry, 2010), ethereal extract by acid hydrolysis, crude fiber, crude protein and moist (Animal- cbaa, 2009).

For the microbiological assessment, the purchased feeds were all homogenized in small packages. Amounts of $25 \mathrm{~g}$ were taken from each package and they were added to $225 \mathrm{ml}$ of peptone saline solution each, reaching the dilution of $10-1$, from which other decimal solutions were diluted up to 10-3.

The microbiological analyses were performed to detect the presence of Salmonella, to assess coliforms at $35^{\circ} \mathrm{C}$ and $45^{\circ} \mathrm{C}$ (Silva et al. 2007) and, to determine the quantity of fungi present (Silva, Junqueira \& Silveira, 2017).

The fungal determination was performed through the cultivation of giant colonies (RIDELL, 1950) and micro fungal cultivation, which enabled the analysis of fruitification bodies. The comparison to ATCC strains was performed for the identification of the fungi (Minami, 2003). The ATCC strains used were Aspergillus flavus (ATCC 16883), Aspergillus ninger (ATCC 6275), Aspergillus nomius (ATCC 15546), Aspergillus parasiticus (ATCC 15517), Penicillium citrinum (ATCC 28752) e Penicillinum expansum (ATCC 40110).

The determination and identification of aflatoxin by thin-layer chromatography (TLC) was done through the preparation of the samples for extraction. From the samples obtained, amounts of 50g (duplicated) were taken. These were homogenized during five minutes in liquid solutions of methanol $(270 \mathrm{ml})$ and KCL $4 \%$ (30 ml). Then, the extract was filtered through Whatman paper, and $150 \mathrm{ml}$ were collected.

A purification stage was done after the extraction by adding $150 \mathrm{ml}$ of clarifying solution (CuSO4 10\%) and celite in powder to the filtered solution, which was homogenized with a glass stick and filtered again. 
Then, a 500ml funnel was used to perform a liquid-liquid extraction. The environment in the funnel where $150 \mathrm{ml}$ were filtered was composed by $10 \mathrm{ml}$ chloroform. $150 \mathrm{ml}$ of distilled water were added and the mix was shaken vigorously for 3 minutes, then it was left quiescent. After a certain amount of time, the chloroformic phase was completely evaporated in water bath at $65^{\circ} \mathrm{C}$.

Subsequently, the residue was ressuspended with $500 \mu \mathrm{l}$ of chloroform, applying $10 \mu \mathrm{L}$ with micro syringe (Hamilton Microliter® Syringes $10 \mu \mathrm{l}$ ) on the chromatographic plate (Sílica gel on TLC-PET foils DC-PET-FOLIEN-KIESELGEL), together with (Sigma - Aldrich: B1, B2, G1 e G2). The revelation of the TLC occurred the toluene-acetate of ethyl-formic acid (50:40:10). After the chromatography the plates were observed under ultra-violet light. The respective retention factors (hRf), according to Moreau and Siqueira (2016), were analysed, exhibiting: Aflatoxin B1with presence of blue fluorescence and hRf $=0,43$, aflatoxin $\mathrm{B} 2$ with presence of blue fluorescence and $\mathrm{hRf}=0,36$, aflatoxin $\mathrm{G} 1$ with presence of blue fluorescence and $\mathrm{hRf}=0,30$, aflatoxin $\mathrm{G} 2$ with presence of blue fluorescence and $\mathrm{hRf}=0,24$.

\section{Results}

The grey values (minerals) for the feeds sold in bulk and in the original packages were respectively as follows: Super premium feeds: $5.51 \%$ and $6.28 \%$. Premium feeds: $11.86 \%$ and $11.9 \%$. Economic feeds: $13.8 \%$ and $12.17 \%$ (Table 1).

The percentages of the ethereal extracts for feeds in bulk and enclosed were respectively: Super premium feeds: $12.48 \%$ and $13.67 \%$. Premium feeds: $11.6 \%$ and $12.28 \%$. Economic feeds: $10.63 \%$ and $12.48 \%$ (Table 1).

The amounts of crude fibers for the feeds purchased in bulk and enclosed in the original packages were respectively: Super premium feeds: $1.77 \%$ and $2.93 \%$. Premium feeds: $2.91 \%$ and $2.58 \%$. Economic feeds: $3.57 \%$ and $5.14 \%$ (Table 1).

The crude protein values obtained in the feeds traded in bulk and enclosed in packages were respectively: Super premium feeds: $32.17 \%$ and $35.59 \%$. Premium feeds: $32.07 \%$ and $33.35 \%$. Economic feeds: $29.76 \%$ and $31.17 \%$ (Table 1).

The values for humidity/ moist were respectively for the feeds sold in bulk and enclosed: Super premium feeds: 7.14\% and 6.25\%. Premium feeds: $7.14 \%$ and $6.68 \%$. Economic feeds: $6.74 \%$ and $4.55 \%$ (Table 1).

Table 1. Bromatological characteristics of petfood sold in bulk and in original packaging.

\begin{tabular}{|c|c|c|c|c|c|c|c|}
\hline & \multicolumn{6}{|c|}{ Petfood kind } & \multirow[b]{2}{*}{$\begin{array}{l}\text { Recommendec } \\
\text { value } \%\end{array}$} \\
\hline & $\begin{array}{r}\text { Sur } \\
\text { Premi }\end{array}$ & $\begin{array}{l}\text { per } \\
\text { imium }\end{array}$ & Prer & nium & Eco & omy & \\
\hline & CA & $\mathrm{CF}$ & CA & $\mathrm{CF}$ & CA & $\mathrm{CF}$ & \\
\hline Minerals & 5,51 & 6,28 & 11,86 & 11,9 & 13,80 & 12,17 & Maximum 12 \\
\hline Ethereal extract & 12,48 & 13,67 & 11,6 & 12,28 & 10,63 & 12,48 & Minimum 12 \\
\hline Crude fiber & 1,77 & 2,93 & 2,91 & 2,58 & 3,57 & 5,14 & Maximum 12 \\
\hline Protein & 31,17 & 35,59 & 31,07 & 33,35 & 29,76 & 31,17 & Maximum 30 \\
\hline Humidity & 7,14 & 6,25 & 7,14 & 6,68 & 6,74 & 4,55 & Minimum 3 \\
\hline
\end{tabular}


Table represents the results obtained in the bromatological analyzes where $\mathrm{CA}=$ Petfood sold in bulk and CF $=$ Petfood sold in its original factory packaging and the reference parameters adapted from Brazilian Pet Food Manual, (2014) and The Association of American Feed Control Officials (AAFCO). Source: Authors.

The presence of coliforms at $35^{\circ} \mathrm{C}, 45^{\circ} \mathrm{C}$ and salmonella spp. was only found in the feeds purchased in bulk, with one of the samples containing coliforms at $35^{\circ} \mathrm{C}$ and the other four samples containing coliforms $45{ }^{\circ} \mathrm{C}$, two of which with salmonella spp. (Table 2).

Table 2. Microbiological characteristics of commercial petfood in bulk and in original packaging.

\begin{tabular}{|c|c|c|c|c|c|c|c|}
\hline & \multicolumn{6}{|c|}{ Petfood kind } & \multirow[b]{2}{*}{ Total } \\
\hline & & um & & im & & ny & \\
\hline & $\mathrm{CA}$ & $\mathrm{CF}$ & CA & $\mathrm{CF}$ & CA & $\mathrm{CF}$ & \\
\hline Coliform at $35^{\circ} \mathrm{C}$ & 0 & 0 & 1 & 0 & 0 & 0 & 1 \\
\hline Coliform at $45^{\circ} \mathrm{C}$ & 2 & 0 & 1 & 0 & 1 & 0 & 4 \\
\hline Salmonella spp & 1 & 0 & 0 & 0 & 1 & 0 & 2 \\
\hline
\end{tabular}

Table represents the results obtained in microbiological analyzes where CA = Petfood sold in bulk and CF = Petfood sold in its original factory packaging. Source: Authors.

The presence of Aspergillus and Penicillium sp. was detected in the feeds sold in bulk (Table 3).

In the presente study, the assessment for the presence of aflatoxin was performed. Contamination was found in $30 \%$ of a total of 30 samples (B1=20\%; B2=3,3\%; G1=3,3\% e G2=13,33\%).

Considering the kinds of feed and the trading in bulk, the highest incidence of aflatoxin occurred in the economic feeds. Among the five samples analyzed, four contained this metabolite, from which sample 11 contained aflatoxin B1 and G2; sample 13 presented aflatoxin B1 and B2. Samples 12 and 14 only contained aflatoxin B1. Sample 15 did not present contamination by aflatoxin. In the premium feeds only one sample presented aflatoxin G2. Among the super-premium feeds, sample 3 contained aflatoxin G2 and sample 4 presented aflatoxin B1 (Table 3).

The feeds traded enclosed in the original packages, the economic one did not have this kind of mycotoxin. In the premium feed only sample 23 presented aflatoxin G1, and sample 18 contained the kind B1 and G2 of the same mycotoxin (Table 3). 
Research, Society and Development, v. 10, n. 1, e54710112239. 2021

(CC BY 4.0) | ISSN 2525-3409 | DOI: http://dx.doi.org/10.33448/rsd-v10i1.12239

Table 3. Fungal and toxicological characteristics in petfoods sold in bulk and in original packaging.

\begin{tabular}{|c|c|c|c|c|c|c|c|}
\hline \multirow[t]{2}{*}{ Petfood } & \multirow{2}{*}{$\begin{array}{c}\text { Sample } \\
\text { code }\end{array}$} & \multicolumn{2}{|c|}{ Fungi } & \multicolumn{4}{|c|}{ Aflatoxin } \\
\hline & & Aspergillus spp. & Penicillium spp. & B1 & B2 & G1 & G2 \\
\hline \multicolumn{8}{|c|}{ Petfood marketed in bulk } \\
\hline \multirow[t]{5}{*}{ Super Preminum } & 1 & + & - & - & - & - & - \\
\hline & 2 & - & - & - & - & - & - \\
\hline & 3 & - & - & - & - & - & + \\
\hline & 4 & + & - & + & - & - & - \\
\hline & 5 & - & + & - & - & - & - \\
\hline \multirow[t]{5}{*}{ Preminum } & 6 & + & - & - & - & - & + \\
\hline & 7 & + & - & - & - & - & - \\
\hline & 8 & + & - & - & - & - & - \\
\hline & 9 & + & - & - & - & - & - \\
\hline & 10 & - & - & - & - & - & - \\
\hline \multirow[t]{5}{*}{ Econômica } & 11 & + & - & + & - & - & + \\
\hline & 12 & - & - & + & - & - & - \\
\hline & 13 & + & - & + & + & - & - \\
\hline & 14 & - & - & + & - & - & - \\
\hline & 15 & - & - & - & - & - & - \\
\hline
\end{tabular}

\begin{tabular}{|c|c|c|c|c|c|c|c|}
\hline \multicolumn{8}{|c|}{ Petfood marketed in the original packaging } \\
\hline \multirow[t]{5}{*}{ Super Preminum } & 16 & - & - & - & - & - & - \\
\hline & 17 & - & - & - & - & - & - \\
\hline & 18 & - & - & + & - & - & + \\
\hline & 19 & - & - & - & - & - & - \\
\hline & 20 & - & - & - & - & - & - \\
\hline \multirow[t]{5}{*}{ Preminum } & 21 & - & - & - & - & - & - \\
\hline & 22 & - & - & - & - & - & - \\
\hline & 23 & - & - & - & - & + & - \\
\hline & 24 & - & - & - & - & - & - \\
\hline & 25 & - & - & - & - & - & - \\
\hline \multirow[t]{5}{*}{ Econômica } & 26 & - & - & - & - & - & - \\
\hline & 27 & - & - & - & - & - & - \\
\hline & 28 & - & - & - & - & - & - \\
\hline & 29 & - & - & - & - & - & - \\
\hline & 30 & - & - & - & - & - & - \\
\hline
\end{tabular}


The table shows the results obtained in microbiological, fungal and toxicological analyzes in bulk commercial petfood and in original packaging, where more represents positive results and represents results with positive results. Source: Authors.

\section{Discussion}

The results of the bromatological analyzes (Table 1) were compared with values and had their values calculated in the Pet Food Brazilian Manual, (2014) and The Association of American Food Control Employees (AAFCO, 2014), because there are not in Brazil specific legislation for pet nutrition.

Thus, the results obtained were compared with what is recommended by non-governmental agencies, according to the minimum and maximum values of nutrients.

In the ash values of all the diets analyzed, only those sold in the open packaging of the economic classification presented a value above of the spec. The problems related to excess mineral matter in the diets are potentially more harmful than the lack thereof, because they cause negative interactions with other nutrients in the diet, which can become a danger to animal health (Case \& Hirakawa, 1997).

As changes in the urinary tract are frequent in the clinical routine Monferdini e Oliveira (2009) report that animal diets are available, because the Brazilian industries have a lower protein content in their substance, and minerals such as calcium, phosphorus and magnesium. upper limits when compared to other countries. This causes the animals to produce alkaline urine, predisposing to the appearance of renal changes (Carciofi, 2007).

The Protein values of the economical petfood sold in open packaging had a result of protein below what is recommended. According to Case (1997), diets with lower protein values may result in a deficit in the animals' organism, insufficient protein provided in the petfood is worse for cats than for dogs, as they are unable to conserve nitrogen in the body, resulting in severe problems in cats (Cappelli et al., 2016).

The measured values of ether extract, crude fiber and isolates were all within the proposed reference value. In the microbiological analyzes of diets sold in bulk, the presence of Salmonella spp. in 13.33\% of the samples.

There are several known Salmonella serotypes and strains that can cause systemic diseases restricted to certain animal species, such as: Salmonella enterica serotype Typhi in humans; Enteric Salmonella serotype Choleraesuis in swine; Salmonella enterica serotype Dublin in cattle; Enteric Salmonella serotype Pullorum and Enteric Salmonella serotype Gallinarum in birds. Other serotypes, such as Typhimurium and Enteritidis, can determine gastrointestinal disease in a broad spectrum of hosts (Volf et al., 2012).

Studies of sources of contamination by Salmonella spp. they are linked mainly in the context of Public Health, where the main sources of infection for humans are sick animals or asymptomatic carriers (Kwaga et al., 1989).

It was found Salmonella spp. in $13.33 \%$ of the total of the analyzed samples and occurred only in the samples of petfood commercialized in bulk. This can be explained by environmental contamination and / or improper handling. Also, the researchers Tezcan-Merdol et al., (2004) affirm that the Salmonella found in the environment can be a source of contamination as well as the manipulator.

In a study by Viel, Degenhardt and D'Agostini (2011), the presence of Salmonella spp. in diets indicated that this pathogen is one of the main contaminants of diets sold in bulk. This result corroborates the results of the present research, in which Salmonellas spp. in quantities of economical and super premium petfood sold in bulk.

The presence of coliforms at $35^{\circ} \mathrm{C}$ and $45^{\circ} \mathrm{C}$, which are well documented zoonotic bacteria, observed in diets sold only in open packaging. These contaminations are common in the raw materials used in the manufacture of cat food (meat, cereals and flour), however, in the extrusion process that consists of high temperatures, it eliminates (Balbani and Bugugan 2001), therefore the positive result it can only be justified by contamination and / or environmental manipulation. 
The presence of filamentous fungi in the list can be a contamination after processing due to the presence of fungal spores that remain viable in the environment and are carried away by air.

Bernardi and Nascimento (2005) also justify this contamination by the fact that fungi are present mainly in the environment. After opening as original packaging, they can go into action when they are not conditioned and / or improperly handled. In the list in which there was fungal growth, there was also an increase in quantity, or that favored the growth of these microbial agents.

In the present study, the highest rate of contamination was by fungi of the Aspergillus genus, which is similar to the results found by several studies (Andrade \& Nascimento (2005); Keller et al. (2005); Santos (2006); Cardoso Filho et al. (2013); and Hillmann et al., (2015).

Copetti et al., (2005) report that petfood contaminated by fungi have a drop in quality, which justifies the variation of the results obtained in the bromatological analyzes.

An aflatoxin B1 was a mycotoxin most found and referred to as the most potent mycotoxin used and one of the most toxic carcinogens known, where the main aflatoxins are B1, B2, G1 and G2 (Romani, 2004; Kumar et al., 2017). The toxicity of aflatoxins decreases in the order B1, B2, G1 and G2 where B1 is twice the toxicity of G1 (Scussel, 2002). (Cho et al., 2000; Sylos \& Rofriguez-Amaya, 1996), a striking presence of aflatoxin B1 in the collection samples that show the potential risk to the health of cats.

Aquino et al. (2011) found a similar result with the presence of toxin-producing fungi in animals captured in birds, domestic rodents and resold in ten pet shops in the São Paulo city. The effects of mycotoxins produced by these fungi are severe and can be fatal for pets (Zain, 2011).

In an experiment carried out by Scudamore et al. (1997) in England, where 100 samples of feed for cats, dogs and birds were collected, a result was obtained of $84 \%$ of the positive samples for the presence of aflatoxins that had a higher contamination result than found in the present study.

The absence of mycotoxin in negative samples for fungi and the presence of positive samples for fungi without mitotoxin is explained by Mazieiro and Bersot, (2010) where the presence of the fungus in the petfood does not necessarily mean that mycotoxins are produced, in the same way, mycotoxin may be present without the presence of the fungus. This is due to the fact that most mycotoxins are thermostable, and resist various heat treatments or dehydration processes, which destroy the fungus that produced them, but not the mycotoxin, in the samples positive for fungus may mean that the fungus, still is not producing the toxin. And so, the authors ratify the arguments of the present research.

\section{Conclusions}

The microbiological results proved that the petfood sold in bulk in the Alfenas city in Minas Gerais state, obtained results with higher incidence of contamination than those sold in their original packaging, showing that when they are exposed to the environment, their microbiological quality may be compromised, which can bring risk to animal health.

The results obtained suggest the need for greater restrictions on the sale of petfood sold in bulk, in order to minimize the depreciation of the product, thus preserving the quality of the petfood.

\section{References}

Andrade, R. M. D., \& Nascimento, J. S. D. (2005). Presença de fungos filamentosos em ração para cães comercializadas na cidade de Pelotas-RS. Rio Grande do Sul.

Animal-CBAA, C. B. D. A. (2009). Guia de métodos analíticos. Sindirações. 
Aquino, S., Morales, M. A., Esper, R. H., Reis, F. C., Manginelli, S., \& Potenza, M. R. (2011). Determinação da contaminação fúngica e análise da atividade de água de rações vendidas a granel no município de São Paulo. Revista de Educação Continuada em Medicina Veterinária e Zootecnia do CRMV-SP, 9(2), 32-32. https://www.revistamvez-crmvsp.com.br/index.php/recmvz/article/view/387

Balbani, A. P. S., \& Butugan, O. (2001). Contaminação biológica de alimentos. Pediatria, 23(4), 320-328. http://files.professorafernandatome.webnode.co $\mathrm{m} / 200000118-38 \mathrm{e} 663 \mathrm{ad} 9 \mathrm{e} /$ Artigo\%20-\%20contaminacao\%20biologica\%20alimento.pdf

Barbosa, I. P., Rodrigues, A. M. D., Muratori, M. C. S., de Sousa Ferreira, M. D., das Chagas Cardoso Filho, F., \& Pereira, M. M. G. (2014). Espécies fúngicas isoladas de ração para gatos comercializadas. PUBVET, 8, 1822-1939. http://www.pubvet.com.br/artigo/1402/p-styletext-align-justifyaligncenterstrongespeacutecies-fuacutengicas-isoladas-de-raccedilatildeo-para-gatos-comercializadasstrongp

Berchieri Junior, A. (1983). Contaminação por Salmonella em farinhas de origem animal utilizadas no preparo de rações. https://pesquisa.bvsalud.org/portal/resource/pt/ses-25028

Berchieri Junior, A., Adachi, S. Y., Calzada, C. T., Paulilo, A. C., Schoken-Iturrino, R. P., \& Tavechio, A. T. (1989). Farinha de carne como fonte de Salmonella em granja avícola. Pesqui. vet. bras, 9-12. https://pesquisa.bvsalud.org/portal/resource/pt/lil-114040

Bernardi, E., \& Nascimento, J. D. (2005). Fungos Anemófilos na praia do Laranjal, Pelotas, Rio Grande do Sul, Brasil. Arquivo do Instituto Biológico de São Paulo, 72(1), 93-97. http://www.biologico.sp.gov.br/uploads/docs/arq/V72_1/bernardi.PDF

Butolo, J. E. (2002). Qualidade de ingredientes na alimentação animal. JE Butolo.

Cappelli, S., Lunedo, P., Freitas, C. P., Raber, H. R., Manica, E., Hashimoto, J. H., \& Oliveira, V. (2016). Avaliação químic a e microbiológica das rações secas para cães e gatos adultos comercializadas a granel. Revista Brasileira de Higiene e Sanidade Animal, 10(1), 90-102. http://www.higieneanimal.ufc.br/seer/index.php/higieneanimal/article/view/304

Carciofi, A. (2007). Como a dieta influencia o pH urinário e a formação de cálculos em cães e gatos. Anais do Simpósio sobre nutrição de animais de estimação. Campinas, CBNA, 13-26.

Cardoso Filho, F. D. C., Calvet, R. M., Rosa, C. A. D. R., Pereira, M. M. G., Costa, A. P. R., \& Muratori, M. C. S. (2013). Monitoramento de fungos toxigênicos e aflatoxinas em rações utilizadas em piscicultura. Ciência Animal Brasileira, 14(3), 305-311. https://www.scielo.br/scielo.php?pid=S1809$68912013000300005 \&$ script=sci_arttext

Case, L. P., Carey, D. P., \& Hirakawa, D. A. (1997). Nutrição canina e felina: manual para profissionais. Harcourt Brace de España.

Cho, J. I., Hong, K. W., \& Kang, K. J. (2000). Control of Aflatoxin Production of Aspergillus flavus by Inghbitory Action of Antagonistic Bacteria. Journal of microbiology and biotechnology, 10(2), 154-160.

Copetti, M. V. (2005). Avaliação micológica de rações comerciais para cães e gatos e potencial micotoxinogênico de espécies selecionadas. https://www.koreascience.or.kr/article/JAKO200011919943913.page

França, J., Saad, F. M. O. B., Saad, C. E. P., Silva, R. C., \& Reis, J. S. (2011). Avaliação de ingredientes convencionais e alternativos em rações de cães e gatos. Revista Brasileira de Zootecnia, 40, 222-231.

Hillmann, F., Novohradská, S., Mattern, D. J., Forberger, T., Heinekamp, T., Westermann, M., ... \& Brakhage, A. A. (2015). Virulence determinants of the human pathogenic fungus a spergillus fumigatus protect against soil amoeba predation. Environmental microbiology, 17(8), 2858-2869.

Horwitz, W. (2010). Official methods of analysis of AOAC International. Volume I, agricultural chemicals, contaminants, drugs/edited by William Horwitz. Gaithersburg (Maryland): AOAC International, 1997. https://sfamjournals.onlinelibrary.wiley.com/doi/abs/10.1111/1462-2920.12808

Keller, m., queiroz, b., keller 1, a. M., ribeiro, j. M. M., \& rosa, c. (2005). Isolados de amostras de rações destinadas a alimentação de equinos no Estado do Rio deJaneiro. Revista Universidade Rural Série Ciências da Vida, 25(1), 93-96.

Klowden, M. J., \& Greenberg, B. (1976). Salmonella in the American cockroach: evaluation of vector potential through dosed feeding experiments. Epidemiology \& Infection, 77(1), 105-111. https://ambridge.org/core/journals/epidemiology-and-infection/article/salmonella-in-the-americancockroach-evaluation-of-vector-potential-through-dosed-feeding-experiments/53ED17AD5774E7ACA944BB4EBBAE4B7C

Kopanic Jr, R. J., Sheldon, B. W., \& Wright, C. G. (1994). Cockroaches as vectors of Salmonella: laboratory and field trials. Journal of food protection, 57(2), 125-135. https://meridian.allenpress.com/jfp/article/57/2/125/166901/Cockroaches-As-Vectors-of-Salmonella-Laboratory

Kumar, P., Mahato, D. K., Kamle, M., Mohanta, T. K., \& Kang, S. G. (2017). Aflatoxins: a global concern for food safety, human health and their management. Frontiers in microbiology, 7, 2170. https://www.frontiersin.org/articles/10.3389/fmicb.2016.02170/full

Kwaga, J. K. P., Adesiyun, A. A., Abdullahi, S. U., \& Bello, C. S. S. (1989). Prevalence of salmonellae, shigellae and Plesiomonas shigelloides in dogs in Zaria, Nigeria. British Veterinary Journal, 145(2), 174-177. https://www.sciencedirect.com/science/article/abs/pii/0007193589901012

Manual Pet Food Brasil (2015). Associação Brasileira da Indústria de Produtos para Animais de Estimação. (8a ed.).

Maziero, M. T., \& Bersot, L. D. S. (2010). Micotoxinas em alimentos produzidos no Brasil. Revista brasileira de produtos agroindustriais, 12(1), 89-99. https://www.cabdirect.org/cabdirect/abstract/20113122465

Minami, P. S. (2003). Micologia: métodos laboratoriais de diagnóstico das micoses. Revista do Instituto de Medicina Tropical de São Paulo, 45(1), 10-10.

Monferdini, R. P., \& Oliveira, J. D. (2009). Nutritional management of dogs and cats with urolithiasis-review. Acta Veterinaria Brasilica, 3(1), 1-4. https://www.cabdirect.org/cabdirect/abstract/20093318813

Moreau, R. L. de M., \& Siqueira, M. E. P. B. de. (2016). Toxicologia Analítica. Guanabara Koogan. 
Research, Society and Development, v. 10, n. 1, e54710112239. 2021

(CC BY 4.0) | ISSN 2525-3409 | DOI: http://dx.doi.org/10.33448/rsd-v10i1.12239

Riddell, R. W. (1950). Permanent stained mycological preparations obtained by slide culture. Mycologia,42(2), 265-270. https://www.tandfonline.com/doi/abs/10.1080/00275514.1950.12017830?journalCode=umyc20

Romani, L. (2004). Immunity to fungal infections. Nature Reviews Immunology, 4(1), 11-24. https://www.nature.com/articles/nri1255?report=reader

Santos, F. C. F. (2006). Fungos em rações para camarões cultivados no Estado do Piauí (Doctoral dissertation, Dissertação (Mestrado em Ciência Animal). Universidade Federal do Piauí, Teresina).

Scudamore, K. A., Hetmanski, M. T., Nawaz, S., Naylor, J., \& Rainbird, S. (1997). Determination of mycotoxins in pet foods sold for domestic pets and wild birds using linked-column immunoassay clean-up and HPLC. Food Additives \& Contaminants, 14(2), 175-186 https://www.tandfonline.com/doi/abs/10.1080/02652039709374512

Scussel, V. M., Lorini, I., \& Mike, L. H. (2002). Fatores que favorecem o desenvolvimento de fungos e produção de toxinas. Lorini, I., Miike, L. H., Scussel, V. M. Armazenagem de grãos. Campinas: IBG.

Silva, N. (2007). Manual de métodos de análise microbiológica de alimentos.

Singh, S. P., Sethi, M. S., \& Sharma, V. D. (1980). The occurrence of salmonellae in rodent, shrew, cockroach and ant. International journal of zoonoses, 7(1), 58-61. https://europepmc.org/article/med/7461919

Sylos, C. M. D., \& Amaya, D. R. (1996). Estudo comparativo de métodos para determinaçäo de aflatoxina M1. Rev. Inst. Adolfo Lutz, 87-97. https://pesquisa.bvsalud.org/portal/resource/pt/lil-176088

Tezcan-Merdol, D. (2004). The Salmonella enterica virulence: Its role in bacterial adaption to mammalian and protozoan cells. Mikrobiologiskt och Tumörbiologiskt Centrum (MTC)/Microbiology and Tumor Biology Center (MTC). https://openarchive.ki.se/xmlui/handle/10616/43211

Varela, S., N., Junqueira, V. C. A., Arruda Silveira, N. F., Taniwaki, M. H., Gomes, R. A. R., \& Okazaki, M. M. (2017). Manual de métodos de análise microbiológica de alimentos e água. Editora Blucher.

Viel, P., Degenhardt, R., \& D’Agostini, F. M. (2014). Presença De Salmonella SPP. Em Fezes De Gatos No Município De Ouro, SC. Unoesc \& CiênciaACBS, 5(2), 203-208.

Volf, J., Stepanova, H., Matiasovic, J., Kyrova, K., Sisak, F., Havlickova, H., \& Rychlík, I. (2012). Salmonella enterica serovar Typhimurium and Enteritidis infection of pigs and cytokine signalling in palatine tonsils. Veterinary microbiology, 156(1-2), 127-135. https://www.sciencedirect.com/science/article/pii/S0378113511005475

Zain, M. E. (2011). Impact of mycotoxins on humans and animals. Journal of Saudi chemical society, 15(2), 129-144. https://www.sciencedirect.com/science/article/pii/S1319610310000827 